\title{
Over-Investment And The Cost Of Debt
}

\author{
Jungeun Cho, Yonsei University, Korea \\ Hyunjung Choi, Yonsei University, Korea
}

\begin{abstract}
In this paper, we examine the association between over-investment and the cost of debt. Using bond yield spreads as a proxy for the cost of debt, we find that over-investment is positively associated with bond yield spreads. This suggests that when firms engage in over-investment, the quality of their financial reporting is lower and business risk is higher. Therefore, investors demand higher risk premiums because of their inability to evaluate firms' financial position and future operating performance efficiently. We also find that the positive association between overinvestment and bond yield spreads is weaker for firms in which managers and foreign shareholders own a high percentage of shares. This same association is stronger for firms in which the largest shareholders own a large proportion of the company. These results imply variation in the effect of over-investment on bond yield spreads according to the ownership structure. Our findings provide empirical evidence that over-investment brings about negative consequences for firms by increasing their external financing costs. This paper contributes to extant literature by using bond yield spreads as a proxy for the cost of debt rather than using credit ratings and interest expenses. Bond yield spreads can be regarded as a more effective measure for the cost of debt because this measure reflects more timely and direct information about decision-making processes of financial market participants when corporate bonds are issued.
\end{abstract}

Keywords: Over-Investment; Bond Yield Spreads; Ownership Structure

\section{INTRODUCTION}

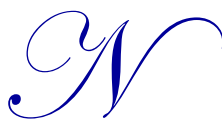

atural conflicts between managers and shareholders are known as agency problems. Conflicts arise because managers have incentives to make business decisions to maximize their own utility; they do not always act in the best interest of shareholders (Jensen and Meckling 1976). As a result, allocation of resources may be inefficient and can even destroy shareholder value (Dominguez-Martinez et al. 2006). Managers have incentives to make self-maximizing decisions, such as expanding firms' businesses to obtain private benefits at the expense of shareholders. These self-maximizing decisions include empire building, and induce managers to undertake over-investment (Jensen 1986). Increasing firm size may serve managers' private interests because they benefit in terms of prestige, power, and compensation when the resources under their control increase (Stulz 1990; Murphy 1985; Jensen and Murphy 1990).

Excessive investment can decrease operating performance and reduce firm value in the long run. Fairfield et al. (2003) find a negative association between growth in net operating assets and one-year-ahead return on assets. Titman et al. (2004) document a negative relation between abnormal capital investment and future stock returns. They provide evidence that firms that substantially increase capital investments tend to achieve lower stock returns in the five subsequent years. They also find that the negative relation between abnormal capital investment and future stock returns is more pronounced for firms with higher cash flows and lower debt ratios in which those firms have greater investment discretion.

Recent studies regarding corporate investment decisions find a negative association between overinvestment and accounting information quality (McNichols and Stubben 2008; Biddle et al. 2009; Choi and Kwak 2010). Lower-quality accounting information can provide incentives for over-investment because it increases information asymmetry and prevents shareholders from effectively monitoring managers' investment activities. Biddle et al. (2009) provide evidence that higher-quality financial reporting is negatively associated with over- 
investment by reducing information asymmetry between managers and outside suppliers of capital. McNichols and Stubben (2008) find evidence of over-investment in firms investigated by the Securities and Exchange Commission for accounting irregularities, firms sued by their shareholders for inappropriate accounting, and firms that restate financial statements during periods in which misreporting occurs. Choi and Kwak (2010) assert that borrowing firms have incentives to manage earnings to facilitate external financing; thus, they over-invest using the external funds. These studies suggest that when information asymmetry exists between managers and outside investors, managers are likely to over-invest to maximize their own utility, resulting in agency problems.

In this study, we examine the relationship between over-investment and the cost of debt. We utilize bond yield spreads as a proxy for the cost of debt to determine whether bondholders demand higher risk premiums for bonds issued beyond bond yields for risk-free assets such as Treasury bonds. Investors in firms that over-invest are more likely to demand higher risk premiums than investors in other firms because the lower-quality accounting in the former prevents effective evaluation of future cash flows and operating performance (Sengupta 1998; Francis et al. 2005). Moreover, excessive investment leads to higher business risk and increased uncertainty about firm prospects (Chen 2010). In response to the increased business risk caused by over-investment, investors demand higher risk premiums. We therefore postulate that over-investment also leads to higher bond yield spreads for firms that issue bonds for financing. Finally, we investigate variations in the effect of over-investment on bond yield spreads depending on ownership structure (managerial ownership and the percentage of firms owned by foreign shareholders and largest shareholders).

Using a sample of firms listed on the Korea Stock Exchange over the period 2006 to 2012, we use measures of over-investment developed by McNichols and Stubben (2008). In addition, we define bond yield spreads as the difference between corporate bond yields on the issue date and Treasury bond yields of similar duration on the same day. The results of an empirical analysis show that over-investment is positively associated with bond yield spreads, and that corporate ownership structure affects this positive association. Specifically, the positive relation between over-investment and bond yield spreads is weaker for firms in which managers and foreign shareholders own a high percentage of shares. Since managerial ownership and ownership by foreign investors alleviates agency problems and information asymmetry between managers and shareholders, managers may have less incentive to engage in over-investment for their own utility under these circumstances, which results in a lower cost of debt. In addition, the effect of over-investment on bond yield spreads is stronger for firms in which the largest shareholders own a large proportion of the company, implying that the largest shareholders may transfer minority shareholders' wealth to themselves to maximize their own wealth. As a result, investors demand high risk premiums for the bonds issued.

This study contributes to the extant literature in the following ways. First, we demonstrate the negative consequences of over-investment by showing that the cost of debt increases when firms engage in over-investment. Many earlier studies analyzed the relationship between financial reporting quality and investment decision-making. This study provides empirical evidence of how corporate bond markets value over-investment. Second, we use bond yield spreads as a proxy for the cost of debt instead of credit ratings and interest expenses, which have been frequently used in previous studies. Bond yield spreads provide useful information about risk premiums demanded by investors for bond-issuing firms. Also, bond yield spreads reflect more timely and direct information regarding bondholders' decision-making, as bond prices and interest rates are determined whenever bonds are issued. Finally, this study provides evidence that the effect of over-investment on the cost of debt depends on variations in firm ownership structure.

The remainder of the paper is organized as follows. In Section 2, relevant prior literature is reviewed and the hypotheses are developed. In Section 3, the research design and sample selection process are outlined. Section 4 presents the empirical results, and Section 5 concludes this study.

\section{LITERATURE REVIEW AND HYPOTHESIS DEVELOPMENT}

\section{Over-Investment}

Researchers have long recognized that managers' allocation of resources may be inefficient and undermine investors' value. Jensen (1986) documents that managers have incentives to expand business for their own private 
benefit, even though increasing firm size may not necessarily be in the best interest of shareholders. This is called managerial empire building; it motivates managers to undertake over-investment. Executives are more likely to be empire builders if their activities are not controlled by some tight form of governance (Dominguez-Martinez et al. 2006). Managers engage in over-investment in order to increase firm size and their own prestige, power, and compensation (Stulz 1990; Murphy 1985; Jensen and Murphy 1990). Therefore, over-investment is indicative of a conflict of interest between managers and investors.

Recent studies examine the relationship between accounting information quality and investment decisionmaking (Biddle and Hilary 2006; Chang et al. 2009; McNichols and Stubben 2008; Biddle et al. 2009). Biddle and Hilary (2006) find that higher-quality accounting information contributes to investment efficiency by reducing information asymmetry between managers and outside suppliers of capital. Chang et al. (2009) report that auditor quality affects the financing choices of firms; they show that firms audited by large auditors are more likely to issue equity as opposed to debt and to have more equity built into their capital structure. Francis et al. (2009) find that corporate transparency facilitates the allocation of resources across industry sectors, resulting in higher investment efficiency.

McNichols and Stubben (2008) investigate the effect of earnings management on investment decisionmaking,examining firms that were subject to accounting-related enforcement action by the Securities and Exchange Commission for accounting irregularities, firms sued by their shareholders for inappropriate accounting, and firms that restated their financial statements. They find that firms with earnings manipulation have greater investment levels than expected based on their investment opportunities during the period earnings are manipulated. Choi and Kwak (2010) examine the relationship between earnings management and over-investment in firms listed on the Korea Stock Exchange. The results show that earnings management is positively associated with over-investment. In addition, they find that this association is more pronounced for firms with greater external financing, suggesting that borrowing firms are more likely to manage earnings to facilitate external financing than other firms. Biddle et al. (2009) provide evidence of a conditional negative (positive) association between financial reporting quality and investment for firms in which managers are likely engage in over-investment (under-investment). Park and Kwon (2012) show that the percentage of foreign ownership in Korean firms is negatively associated with both overinvestment and under-investment. These results imply that foreign investors monitor and discipline the managers of firms, thus facilitating investment efficiency.

\section{Accounting Information Quality And The Cost Of Debt}

Managers have access to information regarding their firms' present financial position and pertinent to their future performance. Thus, they have incentives to decrease information asymmetry between managers and outside investors and enhance the quality of accounting information in order to reduce the cost of capital. On the other hand, firms with high information asymmetry between managers and outside investors have high capital costs because investors lack adequate information to predict future firm performance, and are thus less willing to invest. Prior research on the cost of debt capital documents that the quality of financial disclosure facilitates better prediction of firm value and future cash flows, resulting in a lower cost of debt, as reflected in bond prices and credit ratings.

Sengupta (1998) provides evidence that firms that receive high disclosure quality ratings from financial analysts have lower effective interest costs when issuing debt. Further, the impact of disclosure quality on the cost of debt is greater in circumstances of high market uncertainty. Francis et al. (2005) find that high accruals quality is associated with a lower cost of debt, suggesting that better-quality accruals reduce information risk, thus increasing bond prices. Ahmed et al. (2002) and Zhang (2008) show that investors require lower interest rates for firms with conservative accounting policies, implying that accounting conservatism plays an important role in reducing the cost of debt.

Graham et al. (2008) examine the effect of financial restatement on bank loan contracting, showing that loans initiated after restatement have significantly higher spreads, shorter maturities, more covenant restrictions, and a higher tendency to be secured than other loans. These results suggest that banks place tighter restrictions on loan contract terms to compensate for the information risk implied by financial restatement. Lee et al. (2008) document that the lower disclosure quality associated with Korean firms designated as "unfaithful disclosure" firms on the 
Korean Exchange market resulted in a higher cost of debt. These results are consistent with the perception of poor disclosure quality as a bad sign by stock market participants, and the consequent increase in the cost of debt. Park et al. (2011) investigate the impact of discretionary accruals on the cost of debt using bond yield spreads. They report that larger discretionary accruals result in higher bond yield spreads due to increased information risk. Moreover, they argue that the negative relation between discretionary accruals and bond yield spreads is more pronounced for firms with low credit ratings.

Kim et al. (2011) and Dhaliwal et al. (2011) provide evidence of higher debt costs for firms that disclose internal control weaknesses (ICW), as outlined in Section 404 of the Sarbanes-Oxley Act. Specifically, Dhaliwal et al. (2011) argue that the increase in the cost of debt caused by ICW is more pronounced for firms that are not subject to bank monitoring than for firms that are subject to bank monitoring. Kim et al. (2011) observe that banks reduce loan rates after remediation of previously reported ICW. Sohn and Chung (2010) identify significant declines in the cost of debt capital for Korean firms with newly adopted internal controls over their financial reporting systems. The Korean government passed new accounting legislation in April 2004 following the implementation of Section 404 of the Sarbanes-Oxley Act to ensure more effective monitoring of firms' internal control systems. Sohn and Chung (2010) also find more significant increases in the cost of debt for firms with material weaknesses and those with scope limitations.

\section{Hypothesis Development}

Prior studies document that lower-quality financial reporting results in inefficient investment by increasing information asymmetry between managers and outside investors (Biddle and Hilary 2006; Biddle et al. 2009). Further, a relationship has been reported between earnings manipulation and over-investment (McNichols and Stubben 2008; Choi and Kwak 2010). These findings suggest an association between over-investment and lowquality accounting information. Thus, investors in over-investing firms are more likely to demand higher risk premiums due to their inability to predict future operating performance and cash flows accurately. In addition, excess investment (that which is greater than expected based on the value of the available investment opportunities) results in corporate growth beyond the optimal size, increased business risk, and high uncertainty about firm prospects. Therefore, investors require higher risk premiums to compensate for business risk resulting from overinvestment. Therefore, we predict that over-investment will cause investors to demand high risk premiums, resulting in a higher cost of debt. Using bond yield spreads as a proxy for the cost of debt, we form the following hypothesis:

Hypothesis 1: Over-investment is positively associated with bond yield spreads.

We also posit that the relation between over-investment and the cost of debt is likely to vary with the ownership structure. We examine the effects of managerial ownership, foreign shareholders' ownership, and largest shareholders' ownership on the association between over-investment and bond yield spreads. Agency problems between managers and shareholders are generally caused by the separation of ownership and control (Jensen and Meckling 1976). Strong separation is manifested when managers own only a small percentage of shares in the firm (Lafond and Roychowdhury 2007). Lower managerial ownership may prompt managers to make self-maximizing decisions rather than creating value for shareholders, resulting in agency problems. On the other hand, as the percentage of shares owned by managers increases, agency problems are mitigated because their wealth is tied to firm value. Hence, firms with high managerial ownership are more likely to make investment decisions that will improve future firm performance rather than achieving private benefits for themselves. Even when over-investment does occur in firms with high managerial ownership, investment decision-making is likely to be based on specific information about firms' future operating prospects, information to which managers are specifically privileged to have access. Thus, over-investment in firms with high managerial ownership is less likely to cause agency problems and increase business risk. Therefore, investors may require lower risk premiums, leading to lower bond yield spreads. Based on this reasoning, we predict a weaker positive association between over-investment and bond yield spreads for firms with high managerial ownership offering the following hypothesis:

Hypothesis 2-1: Managerial ownership affects the association between over-investment and bond yield spreads. 
There are two conflicting views as to the role of the largest shareholders. According to the convergence-ofinterests hypothesis, the largest shareholders play an active role in monitoring managers because their wealth is significantly influenced by the operating results of firms. Largest shareholders are in an easier position to obtain information about managers' decisions, and this advantage increases as their ownership increases (Jensen and Meckling 1976). Thus, in over-investing firms in which the largest shareholders own a large proportion of shares, managers may be less likely to make self-maximizing investment decisions because their activities are monitored by the largest shareholders. Such firms have lower bond yield spreads when they issue bonds for financing, since agency problems are mitigated. Accordingly, the positive association between over-investment and bond yield spreads is likely to be weaker for firms in which the largest shareholders own a high proportion of the shares in the company.

On the other hand, the expropriation-of-the-minority-shareholders hypothesis posits that the largest shareholders act in such a way as to destroy investor value by transferring the wealth of minority shareholders to themselves (La Porta et al. 1999). By controlling managers' activities, they attempt to exploit the minority shareholders to maximize their own utility. In these circumstances, over-investment can reduce future cash flows and operating performance because investment decisions are likely to be made with the intention to expropriate minority shareholders' interests, and because the behavior of the largest shareholders is not effectively controlled. Therefore, over-investment in firms in which the largest shareholders own a high proportion of the company's shares will result in an increase in the cost of debt, agency problems, and business risk. According to this hypothesis, the positive association between over-investment and bond yield spreads is likely to be stronger for firms in which the largest shareholders own a high proportion of shares in the company. Therefore, we state the following hypothesis:

Hypothesis 2-2: The proportion of largest shareholders' ownership affects the association between over-investment and bond yield spreads.

Ownership by foreign investors has continually increased since the Korean stock market opened to foreign investors in late 1992. For example, the percentage of foreign ownership in all listed Korean companies in 2001 was $32.75 \%$ based on market capitalization data. This figure rapidly increased to $43.92 \%$ in 2003. Although it declined to $27.22 \%$ in 2008 due to the global recession, the percentage of shares owned by foreign shareholders recovered to $30.56 \%$ in 2011. Hence, foreign shareholders exert significant influence on the Korean capital market and in individual firms. Previous studies report that foreign investors are well equipped to analyze financial information about firms. Their abilities allow them to serve as effective external monitors of managers' business decisions (Cheon 2003; Ahn et al. 2005). Their presence contributes to the alleviation of information asymmetry and improves the quality of accounting information. Therefore, when foreign investors own a large proportion of a company's shares, the quality of accounting information is likely to be high. Even if managers of firms with high foreign ownership engage in over-investment, they have less incentive to over-invest for their own private benefit because the foreign shareholders continuously monitor and control managers' investment decisions. Thus, over-investment in firms with high foreign ownership is less likely to result in poor accounting quality and increased business risk, and more likely to be associated with a lower cost of debt. Therefore, we expect that a weaker positive association between over-investment and bond yield spreads for firms with high foreign ownership. Hence, we present the following hypothesis:

Hypothesis 2-3: Foreign shareholders' ownership affects the association between over-investment and bond yield spreads.

\section{RESEARCH DESIGN AND SAMPLE DESCRIPTION}

\section{Over-Investment Estimation Model}

We use the measure of over-investment developed in the study of McNichols and Stubben (2008), who define over-investment as investment that exceeds the optimal level given a firm's investment opportunities. McNichols and Stubben (2008) measure over-investment using the following equation. 


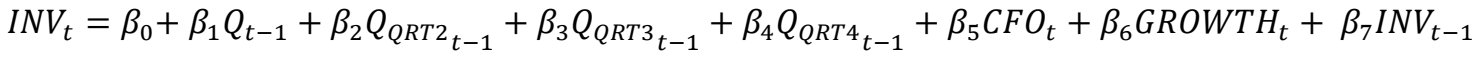

$$
\begin{aligned}
& +\varepsilon_{t}
\end{aligned}
$$

where:

$I N V=$ capital expenditures

= cash outflow from investing activities / net property, plant, and equipment

$Q_{-} Q R T 2\left(Q_{-} Q R T 3, Q_{-} Q R T 4\right)=\mathrm{Q} \times$ an indicator variable to partition Tobin's $\mathrm{Q}$ into quartiles $(1$ if $\mathrm{Q}$ belongs to the second (third, fourth) quartile of its industry-year distribution, and 0 otherwise)

$C F O=$ cash flow from operations / net property, plant, and equipment

GROWTH $=\ln$ (total assets / total assets at the beginning of the year)

Modigliani and Miller (1958) assert that investments depend only on investment opportunities in perfect capital markets. Tobin (1969) shows that marginal $Q$ reflects investment opportunities. In addition, Hayashi (1982) identifies conditions in which the marginal $Q$ is equal to the average $Q$, providing a framework often used in the finance and economics literature. $C F O$ is included to control for firms' internal financing capability. McNichols and Stubben (2008) modify Tobin's $Q$ model by controlling for asset growth, past investment level, and the variation in the relationship between investment and Tobin's $Q$. Asset growth at the beginning of the year is included to control for the possibility that high-growth firms are more likely to invest. Past investment level is another control variable used to capture a firm-specific component of investment decision-making not explained by the other variables in the model. Finally, in order to allow for variations across firms in the same industry-year given the association between investment and Tobin's $Q$, McNichols and Stubben (2008) include incremental coefficients of the quartiles of Tobin's $Q$.

\subsection{Regression Model}

We use the following equation to test Hypothesis 1, which examines the association between overinvestment and bond yield spreads.

$$
\begin{gathered}
\text { SPREAD }_{t}=\beta_{0}+\beta_{1} \text { OINVEST }_{t-1}+\beta_{2} \text { SIZE }_{t-1}+\beta_{3} L_{E V} V_{t-1}+\beta_{4} \text { ROA }_{t-1}+\beta_{5} \text { CFO }_{t-1}+\beta_{6} \text { RATE }_{t-1} \\
+\beta_{7} \text { MATURITY }_{t-1}+\beta_{8} \text { ISSUE }_{t}+\beta_{9} \text { CALL }_{t}+\sum \text { Industry }+\sum \text { Year }+\varepsilon_{t}
\end{gathered}
$$

where:

SPREAD $=$ the difference between corporate bond yields on the issue date and Treasury bond yields with similar duration on the same day

OINVEST $=$ over-investment estimated from the model of McNichols and Stubben (2008)

$S I Z E=$ natural $\log$ of total assets

$L E V=$ book value of debt deflated by total assets

$R O A=$ net income deflated by total assets

$C F O=$ cash flow from operations deflated by total assets

$R A T E=$ numeric value corresponding to the Korea Investors Service (KIS) debt rating in year t. KIS assigns a value of 20 when a bond rating is the best class and a value of 1 when it belongs to an uncollectable bond class

MATURITY = maturity of the issue (year)

$I S S U E=$ size of bond issuance (billion won)

$C A L L=$ indicator variable that equals one when the bond is issued with a call option and zero otherwise

$M O W N=$ managerial ownership

$L O W N=$ largest shareholders' ownership

$F O W N=$ foreign shareholders' ownership

The dependent variable, bond yield spreads, is defined as the difference between corporate bond yield spreads on the issue date and Treasury bond yields with similar duration on the same day. We use returns from the bond issuance on the maturity date because bonds are generally issued at face value in the Korean bond market (Kim and Jung 2009). Our main explanatory variable is over-investment, which is measured using a model developed in 
the study of McNichols and Stubben (2008). We hypothesize that over-investment is positively related to bond yield spreads; thus, we expect to observe significantly a positive coefficient for OINVEST.

As control variables, we include firm size (SIZE), leverage ( $L E V)$, return on assets $(R O A)$, cash flows from operations $(C F O)$, and credit ratings (RATE) to control for bond issuing firm characteristics. Since larger firm size (SIZE) leads to lower information asymmetry and a greater liquidation value when firms become insolvent, bondholders demand lower bond yield spreads for large firms (Kaplan and Urwitz 1979; Sengupta 1998). The likelihood of default and interest expenses are higher in firms with high leverage ( $L E V)$; therefore, we predict bond yield spreads to be increased in these firms (Kaplan and Urwitz 1979; Kim and Kim 2012). In addition, firms with high returns on assets $(R O A)$ and cash flows from operations $(C F O)$ issue bonds with lower interest rates, resulting in lower bond yield spreads (Kaplan and Urwitz 1979; Sengupta 1998). For firm credit ratings (RATE), we use the bond issuers' credit ratings compiled by KIS. The ratings range from AAA (highest rating) to D (lowest rating debt in payment default). These ratings reflect an evaluation of the creditworthiness of the bond issuer with respect to the amounts of principal and interest. KIS assigns a value of 20 when a bond rating is in the highest class (AAA) and a value of 1 when it belongs to an uncollectable bond class (D). Lower credit ratings indicate higher bond yield spreads (Park et al. 2011).

We also control for the characteristics of issued bonds such as bond maturity (MATURITY), the size of bond issuance (ISSUE), and bonds issued with call options (CALL). We include bond maturity (MATURITY) because bonds with longer maturity are more volatile, have higher interest rates, and are more likely to default. All these factors are associated with higher bond yield spreads. A large bond issuance (ISSUE) decreases bond yield spreads due to the rules of economy of scale (Bhojraj and Sengupta 2003). Further, bonds issued with call options (CALL) have lower bond yield spreads and higher returns than bonds issued without call options (Bhojraj and Sengupta 2003).

We estimate the following regression model to test Hypothesis 2, which states that the ownership structure affects the positive association between over-investment and bond yield spreads.

$$
\begin{aligned}
\text { SPREAD }_{t}=\beta_{0}+ & \beta_{1} \text { OWNERSHIP }_{t-1}+\beta_{2} \text { OWNERSHIP } \times \text { OINVEST }_{t-1}+\beta_{3} \text { OINVEST }_{t-1}+\beta_{4} \text { SIZE }_{t-1} \\
& +\beta_{5} \text { LEV }_{t-1}+\beta_{6} \text { ROA }_{t-1}+\beta_{7} \text { CFO }_{t-1}+\beta_{8} \text { RATE }_{t-1}+\beta_{9} \text { MATURITY }_{t}+\beta_{10} \text { ISSUE }_{t} \\
& +\beta_{11} \text { CALL }_{t}+\sum \text { Industry }+\sum \text { Year }+\varepsilon_{t}
\end{aligned}
$$

where:

$M O W N=$ managerial ownership

$L O W N=$ largest shareholders' ownership

$F O W N=$ foreign shareholders' ownership

See equation (2) for definitions of other variables

The dependent variable is identical to that used in equation (2) to test Hypothesis 1. To examine ownership structure, we use managerial ownership $(M O W N)$, largest shareholders' ownership $(L O W N)$, and foreign shareholders' ownership $(F O W N)$. The primary explanatory variable in equation (3) is OWNERSHIP $\times$ OINVEST, which is an interaction term used to examine whether the effect of over-investment on bond yield spreads varies with the ownership structure.

If the positive association between over-investment and bond yield spreads is stronger for firms with higher levels of managerial (largest shareholders' or foreign shareholders') ownership, the sign of the coefficient of OWNERSHIP $\times$ OINVEST is expected to be positive. On the other hand, if the positive relationship between overinvestment and bond yield spreads is weaker for firms with higher levels of managerial (largest shareholders' or foreign shareholders') ownership, we expect to observe a negative coefficient of OWNERSHIP $\times$ OINVEST. 


\section{Sample Selection}

We include companies satisfying the following criteria: (1) companies listed on the Korean Stock Exchange from 2006 to 2012, (2) companies with bond issue data and credit rating data available from Data-guide Pro of the Fn-Guide, (3) companies (except financial institutions) with their accounts closing in December, (4) companies with ownership data from TS2000 of the Korea Listed Companies Association, and (5) companies with financial statements available from the KIS-Value database of KIS. In addition, to eliminate the effect of outlier bias, the top and bottom $1 \%$ of the independent and dependent variables are winsorized. Table 1 shows the sample selection process of this study. We use 202 firm-year observations, and the total number of bonds issued is 434 . We use 434 issued bonds in our analysis.

Table 1: Sample Selection

\begin{tabular}{lc}
\hline Criteria & Number of Bonds \\
\hline Total bonds issued by the Korean Stock Exchange from 2006 to 2012 & 549 \\
Less: Bonds issued by financial institutions & $(16)$ \\
Less: Bonds issued by non-December 31 year-end firms & $(7)$ \\
Less: Bonds without ownership data & $(21)$ \\
Less: Bonds without necessary data for over-investment & $(20)$ \\
Less: Bonds without financial statements & $(51)$ \\
\hline Final Sample & 434 \\
\hline
\end{tabular}

\section{EMPIRICAL RESULTS}

\section{Descriptive Statistics}

The descriptive statistics for the variables used in this study are presented in Table 1. Panel A presents descriptive statistics for issued bonds. The mean (median) value of bond yield spreads (SPREAD), which is the dependent variable in this study, is $2.7 \%$ (2.3\%). The maturity of issued bonds (MATURITY) is approximately 1.570 years on average, and the size of bond issuance (ISSUE) is 23.223 billion Korean won on average. In addition, $13.9 \%$ of all bonds in the sample are bonds issued with call options $(C A L L)$. Panel B provides the descriptive statistics for bond issuers. The mean value for managerial ownership $(M O W N)$ is $8.9 \%$, implying that managers own $8.9 \%$ of all issued stocks. The mean (median) value for largest shareholder ownership ( $L O W N$ ) is $24 \%$ (22.9\%). The average foreign shareholder ownership $(F O W N)$ is $10.6 \%$, suggesting that $10.6 \%$ of issued shares are owned by foreign investors. The mean of the credit rating variable $(R A T E)$ for bond issuers is approximately 8.560 , and the median is 8.000 .

Table 3 provides the correlations between the variables used in this study. Over-investment (OINVEST), which is the independent variable, is negatively correlated with bond yield spreads (SPREAD), although the correlations are not significant. Also, SPREAD is positively correlated with leverage ( $L E V)$ and negatively correlated with return on assets $(R O A)$ and cash flows from operations (CFO). Further, credit rating (RATE) and bond maturity (MATURITY) are significantly and negatively correlated with SPREAD. Because univariate tests are easily influenced by other correlated omitted variables that can affect $S P R E A D$, we perform regression analyses by including control variables. 
Table 2: Descriptive Statistics

\begin{tabular}{|c|c|c|c|c|c|}
\hline \multicolumn{6}{|c|}{ Panel A: Descriptive Statistics for Issued Bonds } \\
\hline Variable & Mean & Q1 & Median & Q3 & Std. Dev. \\
\hline SPREAD & 0.027 & 0.008 & 0.023 & 0.037 & 0.024 \\
\hline MATURITY (years) & 1.570 & 1.000 & 2.000 & 2.000 & 0.714 \\
\hline ISSUE (billion won) & 23.223 & 2.500 & 10.000 & 20.000 & 43.873 \\
\hline CALL & 0.139 & 0.000 & 0.000 & 0.000 & 0.346 \\
\hline \multicolumn{6}{|c|}{ Panel B: Descriptive Statistics for Issuer } \\
\hline Variable & Mean & Q1 & Median & Q3 & Std. Dev. \\
\hline$M O W N$ & 0.089 & 0.000 & 0.016 & 0.134 & 0.141 \\
\hline$L O W N$ & 0.240 & 0.000 & 0.229 & 0.406 & 0.210 \\
\hline FOWN & 0.106 & 0.009 & 0.056 & 0.127 & 0.204 \\
\hline SIZE (billion won) & 2,963 & 881 & 1,770 & 3,227 & 3,766 \\
\hline$L E V$ & 0.645 & 0.591 & 0.658 & 0.729 & 0.135 \\
\hline$R O A$ & 0.005 & -0.019 & 0.010 & 0.036 & 0.089 \\
\hline$C F O$ & 0.004 & -0.033 & 0.009 & 0.047 & 0.073 \\
\hline RATE & 8.560 & 7.000 & 8.000 & 10.000 & 3.220 \\
\hline
\end{tabular}

$S P R E A D=$ the difference between corporate bond yields on the issue date and Treasury bond yields with similar duration on the same day

MATURITY = maturity of the issue (year)

ISSUE = size of bond issuance (billion won)

$C A L L=$ indicator variable that equals one when the bond is issued with a call option and zero otherwise

$M O W N=$ managerial ownership

$L O W N=$ largest shareholders' ownership

$F O W N=$ foreign shareholders' ownership

$S I Z E=$ natural log of total assets

$L E V=$ book value of debt deflated by total assets

$R O A=$ net income deflated by total assets

$C F O=$ cash flows from operations deflated by total assets

$R A T E=$ numeric value corresponding to the KIS debt rating in year t. KIS assigns a value of 20 when a bond rating is in the best class and a value of 1 when it belongs to an uncollectable bond class 


\begin{tabular}{|c|c|c|c|c|c|c|c|c|c|c|c|c|c|}
\hline & SPREAD & OINVEST & MOWN & LOWN & FOWN & SIZE & LEV & ROA & CFO & RATE & MATURITY & ISSUE & CALL \\
\hline SPREAD & 1.000 & & & & & & & & & & & & \\
\hline OINVEST & -0.008 & 1.000 & & & & & & & & & & & \\
\hline$M O W N$ & $-0.089^{*}$ & -0.017 & 1.000 & & & & & & & & & & \\
\hline$L O W N$ & $0.089^{*}$ & -0.012 & 0.019 & 1.000 & & & & & & & & & \\
\hline FOWN & $-0.212^{* * * *}$ & -0.032 & -0.065 & $0.093^{*}$ & 1.000 & & & & & & & & \\
\hline SIZE & 0.019 & 0.063 & $-0.178^{* * * *}$ & 0.025 & $0.188^{* * *}$ & 1.000 & & & & & & & \\
\hline$L E V$ & $0.196^{* * * *}$ & $-0.175^{* * * *}$ & $-0.105^{* *}$ & $-0.301^{* * * *}$ & $-0.300^{* * * *}$ & $-0.107^{* *}$ & 1.000 & & & & & & \\
\hline ROA & $-0.164^{* * *}$ & -0.025 & 0.000 & $0.224^{* * * *}$ & $0.192^{* * * *}$ & $0.217^{* * * *}$ & $-0.417^{* * *}$ & 1.000 & & & & & \\
\hline CFO & $-0.126^{\text {**** }}$ & -0.052 & -0.043 & $0.183^{* * *}$ & $0.135^{* * *}$ & $0.131^{* * *}$ & $-0.213^{* * *}$ & $0.217^{* * *}$ & 1.000 & & & & \\
\hline RATE & $-0.136^{* * * *}$ & $-0.091^{*}$ & -0.024 & $-0.086^{*}$ & $-0.288^{* * * *}$ & $0.643^{* * *}$ & $-0.461^{* * * *}$ & $0.356^{* * *}$ & $0.171^{* * * *}$ & 1.000 & & & \\
\hline MATURITY & $-0.344^{* * *}$ & 0.045 & $0.127^{* * *}$ & $-0.182^{* * * *}$ & 0.063 & $-0.097^{* *}$ & -0.045 & 0.063 & -0.038 & $-0.105^{* *}$ & 1.000 & & \\
\hline ISSUE & 0.017 & $-0.193^{* * *}$ & 0.011 & -0.033 & $0.077^{*}$ & $0.395^{* * *}$ & -0.007 & $0.103^{* *}$ & -0.014 & $-0.291^{* * *}$ & 0.006 & 1.000 & \\
\hline$C A L L$ & -0.044 & -0.024 & 0.003 & 0.011 & -0.033 & $-0.084^{*}$ & $0.147^{\text {**** }}$ & $-0.180^{* * *}$ & -0.033 & $0.173^{* * * *}$ & -0.02 & $-0.098^{* *}$ & 1.000 \\
\hline
\end{tabular}

See Table 2 for variable definitions.

$*, * *, * * *$ denote statistical significance at the $0.10,0.05$, and 0.001 levels, respectively, based on two-tailed tests

\section{Results for Hypothesis 1}

Table 4 presents the results of the testing of hypothesis 1 , which examines whether over-investment is positively associated with bond yield spreads. As a dependent variable, we measure bond yield spreads (SPREAD) by calculating the difference between corporate bond yields on the issue date and Treasury bond yields with similar duration on the same date. We use a model developed by McNichols and Stubben (2008) to measure over-investment (OINVEST) empirically as our main variable of interest.

The results of the regression analysis show that OINVEST has a significantly positive association with SPREAD at the 5\% level. This indicates that firms with a higher tendency to over-invest have higher bond yield spreads. Thus, hypothesis 1 is supported. The results in Table 4 imply that when firms engage in over-investment, the quality of their financial reporting is lower and their business risk is higher. Therefore, investors demand higher risk premiums because of their inability to evaluate firms' financial position and future operating performance efficiently. Hence, firms engaging in over-investment are more likely to have higher bond yield spreads when they issue bonds. With respect to control variables, the coefficient of firm size (SIZE) is significant and negative, whereas the coefficients of leverage (LEV) and maturity of issued bonds (MATURITY) are significant and positive. This suggests that bond yield spreads are lower in larger firms, and bond yield spreads are higher in firms with higher leverage and more mature bonds. Each model's F-statistic is statistically significant; therefore, we conclude that our regression models are appropriate for the analyses. 
Table 4: Results for Hypothesis 1

\begin{tabular}{|c|c|}
\hline & Dependent Variable (SPREAD) \\
\hline Intercept & $0.010(5.59)^{\text {*3** }}$ \\
\hline OINVEST & $0.002(2.29)^{* *}$ \\
\hline$S I Z E$ & $-0.000(-2.60)^{* * *}$ \\
\hline$L E V$ & $0.001(2.90)^{* * * *}$ \\
\hline$R O A$ & $0.001(1.79)^{*}$ \\
\hline $\mathrm{CFO}$ & $-0.004(-0.79)$ \\
\hline RATE & $-0.000(-0.08)$ \\
\hline MATURITY & $0.001(2.01)^{* *}$ \\
\hline ISSUE & $-0.000(-0.51)$ \\
\hline$C A L L$ & $0.001(0.89)$ \\
\hline Industry Dummy & Included \\
\hline Year Dummy & Included \\
\hline Adj. $R^{2}$ & 0.238 \\
\hline F-Value & $4.52^{* * *}$ \\
\hline $\mathrm{N}$ & 434 \\
\hline
\end{tabular}

See Table 2 for variable definitions.

$*, * *, * * *$ denote statistical significance at the $0.10,0.05$, and 0.001 levels, respectively, based on two-tailed tests.

\section{Results for Hypothesis 2}

Table 5: Results for Hypothesis 2

\begin{tabular}{|c|c|c|c|}
\hline \multicolumn{4}{|c|}{$+\beta_{7} \mathrm{CFO}_{t-1}+\beta_{8}$ RATE $_{t-1}+\beta_{9}$ MATURITY $_{t}+\beta_{10} I_{S S U E_{t}}+\beta_{11} C A L L_{t}+\sum_{\text {Industry }}+\sum$ Year $+\varepsilon_{t}(3)$} \\
\hline & Model (1) & Model (2) & Model (3) \\
\hline Intercept & $0.011(6.39)^{* * *}$ & $0.010(5.97)^{* * *}$ & $0.011(6.25)^{* * *}$ \\
\hline$M O W N$ & $0.002(0.92)$ & & \\
\hline$M O W N \times O I N V E S T$ & $-0.021(-2.81)^{* * * *}$ & & \\
\hline$L O W N$ & & $0.000(0.49)$ & \\
\hline$L O W N \times O I N V E S T$ & & $0.010(1.84)^{*}$ & \\
\hline FOWN & & & $0.001(0.47)$ \\
\hline$F O W N \times O I N V E S T$ & & & $-0.024(-3.11)^{* * * *}$ \\
\hline OINVEST & $0.004(3.58)^{* * *}$ & $0.001(0.08)$ & $0.000(0.12)$ \\
\hline SIZE & $-0.000(-2.98)^{* * * *}$ & $-0.000(-2.39)^{* *}$ & $-0.001(-2.60)^{* * * *}$ \\
\hline$L E V$ & $0.001(2.93)^{* * *}$ & $0.001(3.06)^{* * *}$ & $0.001(2.71)^{* * *}$ \\
\hline$R O A$ & $0.001(2.02)^{* *}$ & $0.001(1.48)$ & $0.001(1.67)^{*}$ \\
\hline $\mathrm{CFO}$ & $-0.002(-0.53)$ & $-0.001(-0.86)$ & $-0.004(-0.80)$ \\
\hline RATE & $-0.000(-0.28)$ & $0.000(-0.16)$ & $0.000(0.02)$ \\
\hline MATURITY & $0.001(1.87)^{*}$ & $0.000(1.98)^{* *}$ & $0.001(1.88)^{*}$ \\
\hline ISSUE & $-0.000(-0.43)$ & $-0.000(-0.61)$ & $-0.000(-0.63)$ \\
\hline$C A L L$ & $0.001(1.12)$ & $0.001(0.76)$ & $0.000(0.68)$ \\
\hline Industry Dummy & Included & Included & Included \\
\hline Year Dummy & Included & Included & Included \\
\hline$\overline{\text { Adj. } R^{2}}$ & 0.258 & 0.245 & 0.263 \\
\hline F-Value & $4.66^{* * *}$ & $4.35^{* * *}$ & $4.79^{* * * *}$ \\
\hline $\mathrm{N}$ & 434 & 434 & 434 \\
\hline
\end{tabular}

See Table 2 for variable definitions.

$*, * *, * * *$ denote statistical significance at the $0.10,0.05$, and 0.001 levels, respectively, based on two-tailed tests.

Table 5 reports the results for hypothesis 2, which investigates whether the positive association between 
over-investment and bond yield spreads depends on factors related to ownership. We use managerial ownership $(M O W N)$ in Model (1), largest shareholders' ownership $(L O W N)$ in Model (2), and foreign shareholders' ownership $(F O W N$ ) in Model (3). The results of the regression analysis using Model (1) show that the coefficient of MOWN $\times$ OINVEST, our main variable of interest, is negative and significant at the $1 \%$ level. This means that the positive relationship between over-investment and bond yield spreads is weaker for firms with higher managerial ownership. Agency problems between managers and outside investors (including bondholders) are minimized in firms with high managerial ownership because managers of these firms are more likely to make investment decisions that benefit future firm value. These managers have less incentive to engage in over-investment in order to achieve their own private interests. However, they may still over-invest, expecting that their investment decisions will increase future growth and firm value. Hence, over-investment in firms with high managerial ownership may not increase business risk, and risk premiums may be lower for these firms than in firms with low managerial ownership. In sum, we find a weaker positive relation between over-investment and bond yield spreads in firms with high managerial ownership.

Results using Model (2) indicate that the coefficient of $L O W N \times O I N V E S T$ is positive and significant at the $10 \%$ level, suggesting a more significant relationship between increased bond yield spreads and over-investment in firms in which the largest shareholders own a large proportion of shares. These results are consistent with the expropriation-of-the-minority-shareholders hypothesis in that a firm's largest shareholders do not efficiently monitor managers' opportunistic investment decisions, which can negatively influence future operating performance and cash flows. Such shareholders are interested in expanding the business to increase their own private gains. Under these circumstances, agency problems between managers and outside investors are not mitigated, and higher business risk triggers an increase in bond yield spreads when over-investment occurs in firms with high ownership by the largest shareholders.

The regression results using Model (3) show that the coefficient of FOWN $\times$ OINVEST is significantly negative at the $1 \%$ level. This result implies that the positive association between over-investment and bond yield spreads is weaker for firms in which more shares are owned by foreign shareholders. This can be interpreted as follows. Since foreign investors play an important monitoring role in managers' investment decision-making and contribute to improving the quality of accounting information, even when firms engage in over-investment, those firms are less likely to over-invest to maximize their own interests. Therefore, over-investment by managers of firms with higher foreign ownership is associated with lower risk premiums than in firms with lower foreign ownership.

Collectively, the results in Table 5 document that the positive association between over-investment and bond yield spreads is weaker for firms with high managerial ownership and foreign shareholders' ownership and is stronger for firms with high largest shareholders' ownership. This shows that the ownership structure of firms affects the relation between over-investment and bond yield spreads. Hence, the results support hypothesis 2.

\section{CONCLUSION}

In this study, we investigate the association between over-investment and bond yield spreads as a proxy for the cost of debt. Managers have incentives to engage in over-investment by expanding businesses so that they can increase resources under their control, thereby increasing their own prestige, power, and compensation (Jensen and Meckling 1976; Stulz 1990; Murphy 1985; Jensen and Murphy 1990). This opportunistic investment decisionmaking can reduce profitability and destroy firm value in the long run (Fairfield et al. 2003; Titman et al. 2004). Previous research posits that over-investment is negatively associated with accounting information quality (McNichols and Stubben 2008; Biddle et al. 2009; Choi and Kwak 2010). We predict that bondholders of firms that engage in over-investment require higher risk premiums because the poorer quality of accounting information prevents those investors from efficiently evaluating future cash flows and firm performance. Further, because overexpansion triggers higher business risk, investors are likely to demand high risk premiums for firms that engage in over-investment. Based on these discussions, we examine whether over-investment is positively associated with bond yield spreads. In addition, we investigate whether the ownership structure affects the positive association between over-investment and bond yield spreads. 
The results of the regression analysis show that over-investment is positively associated with bond yield spreads, suggesting that over-investment increases the cost of debt for firms. We also find that the positive association between over-investment and bond yield spreads is weaker for firms with high managerial ownership and high foreign shareholders' ownership. This implies that for firms in which managerial ownership or foreign ownership are high, agency problems between managers and outside investors (including bondholders) are mitigated and the quality of accounting information is high. In this situation, even when managers engage in over-investment, they cannot do so for self-maximizing purposes at the expense of investors. Therefore, bond yield spreads are lower for those firms, even if they engage in over-investment, than for firms with low managerial ownership and foreign ownership. We also find that the positive relation between over-investment and bond yield spreads is stronger for firms in which the largest shareholders own a large proportion of the company, suggesting that they cannot effectively monitor managers' opportunistic investment decisions, as theyare more interested in increasing their own utility by transferring the wealth of minority shareholders to themselves.

This study makes a direct contribution to our understanding of the negative consequences of over-investment by showing that over-investment increases the cost of debt for firms. The results of this study provide evidence regarding how corporate bond markets value over-investment. Further, extant literature has frequently used credit ratings and interest expenses as proxies for the cost of debt. However, we utilize bond yield spreads as a measure of the cost of debt because bond yield spreads provide more timely and direct information and a better reflection of bond investors' decision-making. Finally, this paper provides additional evidence that a firm's ownership structure impacts the positive association between over-investment and bond yield spreads, suggesting that the effect of overinvestment on bond yield spreads varies according to the ownership structure.

\section{AUTHOR INFORMATION}

Jungeun Cho, PhD, School of Business, Yonsei University, 50 Yonsei-ro, Seodaemun-gu, Seoul 120-749, South Korea. E-mail: jecho0805@ hotmail.com (First author)

Hyunjung Choi, Ph.D., School of Business, Yonsei University, 50 Yonsei-ro, Seodaemun-gu, Seoul 120-749, South Korea. E-mail: hyunjung_choi@yonsei.ac.kr (Corresponding author)

\section{REFERENCES}

1. Ahmed, A.S., Billings, B.K., Morton, R.M., Stanford-Harris, M. (2002). The role of accounting conservatism in mitigating bondholder-shareholder conflicts over dividend policy and in reducing debt costs. The Accounting Review, 77, 867-890.

2. Ahn, Y. Y., H. H. Shin, and J. H. Chang. (2005). The relationship between the foreign investor and information asymmetry. Korean Accounting Review, 30, 109-131.

3. Bhojraj, S. and P. Sengupta (2003). Effect of corporate governance on bond ratings and yields: The role of institutional investors and outside directors. Journal of Business, 76 (3), 455-475.

4. Biddle, G., and G. Hilary. (2006). Accounting quality and firm-level capital investment. The Accounting Review 81, 963-982.

5. Biddle, G., G. Hilary, and R. Verdi. (2009). How does financial reporting quality relate to investment efficiency? Journal of Accounting and Economics, 48, 112-131.

6. Chang, X., S. Dasgupta, and G. Hillary. (2009). The effect of auditor quality on financing decisions. The Accounting Review, 84, 1085-1117.

7. Chen, L. (2010). Research on the growth risk of China's small and medium enterprise. International Journal of Business and Management, 5(11), 203-207.

8. Cheon, Y. S. (2003). The association between foreign and domestic institutional ownership and earnings quality. Korean Management Review, 32(4), 1001-1032.

9. Choi, J. S., and Y. M. Kwak. (2010). Association between managerial over-investment propensity and real and accrual-based earnings management. Korean Accounting Review 35(4), 75-131.

10. Dhaliwal, D., C. Hogan, R. Trezevant and M. Wilkins (2011). Internal control disclosures, monitoring, and the cost of debt. The Accounting Review, 86 (4), 1131-1156.

11. Dominguez-Martinez, S., O.H. Swank and B. Visser. (2006). Disciplining and screening top executives. 
Working paper. Erasmus University and Tinbergen Institute.

12. Fairfield, P. M., J. S. Whisenant, and T. L. Yohn. (2003). Accrued earnings and growth: Implications for future profitability and market mispricing. The Accounting Review, 78, 353-371.

13. Francis, J. R., S. Huang, I. K. Khurana, and R. Pereira. (2009). Does corporate transparency contribute to efficient resource allocation? Journal of Accounting Research, 47 (4), 943-989.

14. Francis, J., R. LaFond, P. Olsson and K. Schipper (2005). The market pricing of accruals quality. Journal of Accounting and Economics, 39, 295-327.

15. Graham, J. R., S. Li, and J. Qiu (2008), Corporate misreporting and bank loan contracting. Journal of Financial Economics, 89 (1), 44-61.

16. Hayashi, F., 1983, Tobin's marginal q and average q: A neoclassical interpretation, Econometrica 50: 213224.

17. Jensen, M. C., 1986, Agency cost of free cash flow, corporate finance, and takeovers, American Economics Review 76, 323-329.

18. Jensen, M. C. and W. H. Meckling. (1976). Theory of the firms: managerial behavior, agency costs and ownership structure. Journal of Financial and Economics, 3(4), 305-360.

19. Jensen, M.C., and K. J. Murphy. 1990. Performance Pay and Top-Management Incentives. Journal of Political Economy 98: 225-264.

20. Kaplan, R. S and G. Urwitz (1979), "Statistical Models of Bond Ratings: A Methodological Inquiry," Journal of Business 52 (2), 231-261.

21. Kim, J. B., B. Y. Song, and L. Zhang (2011). Internal control weakness and bank loan contracting: Evidence from SOX section 404 disclosures. The Accounting Review 86(4): 1157-1188.

22. Kim, M. A. and Y. J. Kim (2012). The effect of majority shareholders on the cost of debt. Korean Financial Management Journal, 29(2), 1-28.

23. LaFond, R., Roychowdhury, S. (2008). Managerial ownership and accounting conservatism. Journal of Accounting Research, 46, 101-135.

24. La Porta, R., F. Lopez-de-Silanes and A. Shleifer (1999). Corporate ownership around the world. Journal of Finance, 54(2), 471-518.

25. Lee, A. Y., S. B. Chun, and S. S. Park (2008). The effect of unfaithful disclosure on the cost of debt. Korean Accounting Review, 33(1), 127-158.

26. McNichols, M. F., and S. R. Stubben (2008). Does earnings management affect firms' investment decisions? The Accounting Review, 83, 1571-1603.

27. Modigliani, F., and M. Miller (1958). The cost of capital, corporation finance and the theory of investment, The American Economic Review, 48, 261-297.

28. Murphy, K. J. (1985). Corporate performance and managerial remuneration: An empirical analysis. Journal of Accounting and Economics, 7, 11-42.

29. Park, J. H., and D. H. Kwon. (2010). The impact of foreign ownership on investment efficiency. Korean Accounting Review, 37(3), 277-377.

30. Park, Y. H., H. S. Choi, and H. S. Kim. (2011). The association between discretionary accruals and bond yields. Korean Accounting Journal, 20(4), 35-56.

31. Sengupta, P (1998). Corporate disclosure quality and the cost of debt. The Accounting Review, 73, 459-474.

32. Sohn, S. K. and K. W. Chung. (2010). A Study on the effectiveness of internal control over financial reporting - using cost of debt capital. Korean Journal of Accounting, Taxation and Auditing, 52, 1-25.

33. Stulz, R. (1990). Managerial discretion and optimal financing policies. Journal of Financial Economics, 26, 3-27.

34. Titman, S., K. C. J Wei,and F. Xie. (2004). Capital investments and stock returns. Journal of Financial and Quantitative Analysis 39, 677-700.

35. Tobin, J. (1969). A general equilibrium approach to monetary theory. Journal of Money, Credit and Banking, 1, 15-29.

36. Zhang, J. (2008). The contracting benefits of accounting conservatism to lenders and borrowers. Journal of Accounting and Economics 45, 27-54. 